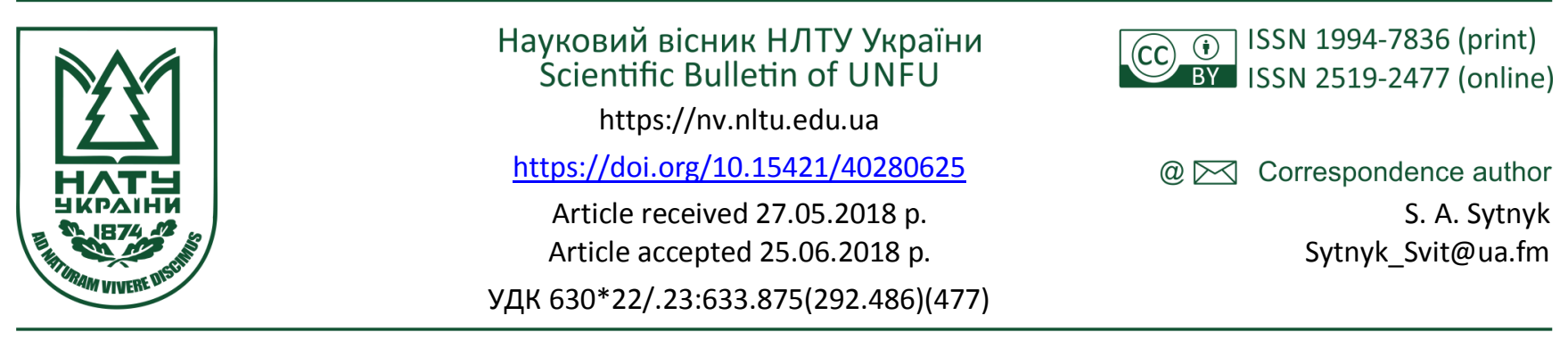

С. А. Ситник, І. В. Рула

Дніпропетровський державний аграрно-економічний університет, м. Дніпро, Украӥна

\title{
ТЕРМІЧНИЙ АНАЛІЗ ДЕРЕВИНИ ТА КОРИ РОБІНІЇ НЕСПРАВЖНЬОАКАЦІЇ В ДЕРЕВОСТАНАХ ПІВНІЧНОГО СТЕПУ УКРАЇНИ
}

За допомогою методів термогравіметрії - термогравіметричної кривої (ТГ), диференціальної термогравіметричної кривої (ДТГ), або кривої інтенсивності зміни маси досліджуваного зразка, досліджено термічну деструкцію деревини і кори головної лісотвірної породи штучних лісових насаджень Північного Степу України - робінії несправжньоакації (Robinia pseudoacacia L.). Термічний аналіз зразків деревини і кори здійснено в окиснювальній (повітря) атмосфері. Встановлено стадії термічного розкладання деревинної речовини і кори в умовах програмованого нагріву до $600{ }^{\circ} \mathrm{C}$ зі швидкістю $10^{\circ} \mathrm{C} / \mathrm{xв}$ (ТГ/ДТГ/ДТА), їх температурні інтервали, втрату маси, інтенсивність втрати маси та теплові ефекти. На основі аналізу величин енергії активації на окремих стадіях термічного розкладання, залежності енергії активації від ступеня конверсії деревини і кори, а також із порівняння втрати маси на відповідних стадіях термодеструкції, теплових ефектів, залишкової маси і інших параметрів ТГ/ДТГ, охарактеризовано деревину і кору робінії. Деревина робінії характеризується значнішою термостабільністю, ніж кора. Запропоновано математичні моделі для оцінювання залежності втрати маси від температури деструкції складників надземної фітомаси (кори, деревини) досліджуваного деревного виду.

Ключові слова: деревина; кора; окиснювальна термодеструкція; термогравіметрія; теплові ефекти.

Вступ. Потреба заміни викопного палива на відновлювальні енергоносії з низьким вмістом вуглецю визначає пріоритетні напрямки досліджень у галузі світової енергетичної безпеки та України зокрема.

Біомаса деревних рослин, що переважно представлена деревиною, може забезпечити альтернативну енергетичну сировину та одночасно зменшити викиди токсичних газів, які супроводжують згоряння вуглеводнів.

Сучасні дослідження демонструють зацікавленість науковців процесами термічного розкладання фітомаси (Poletto et al., 2010; Pandey et al., 2015; Haberle, et al 2017; Guo \& Zhong, 2018).

Особливості цих процесів насамперед зумовлені складом структурних компонентів надземної фітомаси рослин. У складі деревини листяних деревних порід у середньому міститься: лібриформу - 43-75\%, елементів провідної тканини, судин - 20-40\%, серцевинних променів 10-20\%, деревної паренхіми - 2-13\%. Хімічний склад рослинних тканин складний і $є$ видоспецифічним.

Вуглеводний комплекс деревини - холоцелюлоза, до їі складу входять целюлоза, геміцелюлоза, представлена пентозанами і гексозанами та уронові кислоти, які містять карбоксильні, ацетильні групи та метоксіли. Вихід холоцелюлози для листяної деревини змінюється у межах 72-79\%, лігнін - 18-22\%.

Кора деревних рослин зазвичай складається 3 двох шарів: внутрішнього живого - лубу і зовнішнього мер- твого - кірки. За хімічним складом вони є різними, але обидва шари кори значно відрізняються від деревини високим вмістом речовин, що екстрагуються водою, відносно низьким вмістом легко- і важкогідролізованих полісахаридів і целюлози. Гідролізати легкогідролізованих полісахаридів деревної кори, як і гідролізат деревини, містять $D$-галактозу, $D$-манозу, $D$-глюкозу, $L$-арабинозу, $D$-ксилозу і уронові кислоти, але в інших співвідношеннях. Особливістю кори $є$ високий вміст дубильних речовин, а також наявність в корку воскоподібної речовини - суберіну (Órfão et al 1999).

Наявні відмінності хімічного складу деревини і кори зумовлюють різність їх термічних ефектів.

Термічна деструкція деревини як в інертному, так і в окиснювальному середовищі може бути охарактеризована сумою реакцій термічного розкладання зазначених структурних компонентів рослинних тканин. При цьому відомо, що температурні інтервали термічної деструкції цих компонентів фітомаси частково перекриваються (Vichnevsky et al., 2003).

A. Tan та J. Stotta (1989) у своїй роботі описували диференційний термічний аналіз (ДТА) деревини в окиснювальному середовищі та псевдоскраплених шаpax та запропонували використовувати дані ДТА для визначення способу хімічного оброблення та спалювання деревини.

Використання обробленої деревини як біоенергетичної сировини може стати доцільним варіантом змен-

Інформація про авторів:

Ситник Світлана Анатоліївна, канд. біол. наук, доцент, кафедра садово-паркового господарства. Email: Sytnyk_Svit@ua.fm; https://orcid.org/0000-0002-7646-6347

Рула Ірина Василівна, ст. викладач, кафедра хімії. Email: Irina_chem@i.ua

Цитування за ДСту: Ситник С. А., Рула І. В. Термічний аналіз деревини та кори робінії несправжньоакації в деревостанах Північного степу України. Науковий вісник НЛтУ України. 2018, т. 28, № 6. С. 125-128.

Citation APA: Sytnyk, S. A., \& Rula, I. V. (2018). The thermal analysis of wood and bark of black locust stands within northern steppe of Ukraine. Scientific Bulletin of UNFU, 28(6), 125-128. https://doi.org/10.15421/40280625 
шення викидів у виробництві енергії, але це може бути реалізоване лише в разі заміни вугілля та природного газу. Для досягнення істотного зменшення обсягів викидів відповідно до національних та міжнародних цілей у площині зміни клімату, попереднє оброблення відходів деревини потрібне для зменшення компонентів, які утворюють $\mathrm{N}_{2} \mathrm{O}$ під час перетворення енергії. Результати досліджень Röder M. та Thornley, P. (2018) демонструють, що залежно від типу необроблених відходів деревини можна скоротити викиди $\mathrm{N}_{2} \mathrm{O}$ до $91 \%$.

Фізичні та хімічні властивості деревини, такі як щільність, теплоємність, теплопровідність, вміст вологи, співвідношення основних біополімерних компонентів, фізико-хімічні особливості геміцелюлоз, целюлози і лігніну, зміст і якість екстрактивних речовин, визначають параметри термічної деструкції.

На фоні достатньої кількості робіт з термічної деструкції різних деревних порід, немає даних щодо робінії несправжньоакації (Robinia pseudoacacia L.) - інтродукованого виду із Північної Америки.

Безальтернативним джерелом деревини для господарських потреб у Північному Степу України є лісові насадження, які мають переважно штучне походження. У степовій зоні відсутні експлуатаційні ліси, наявні насадження більшою мірою формують дров'яну деревину, попит на яку значно перевищує пропозицію, особливо у сільській місцевості. Третину (17683 га) від площі, вкритої лісовою рослинністю, у Північному Степу України зайнято перестиглими робінієвими деревостанами, тому і було визначено мету дослідження - здійснити аналіз процесів термодеструкції деревини та кори робінії несправжньоакації у лісових культурах Північного Степу України.

Матеріали та методи дослідження. Зразки деревини і кори робінії несправжньоакації (Robinia pseudoacacia L.) було відібрано з 60 модельних дерев на 20 тимчасових пробних площах, закладених у Північному Степу України, у лісових культурах Дніпропетровсько-

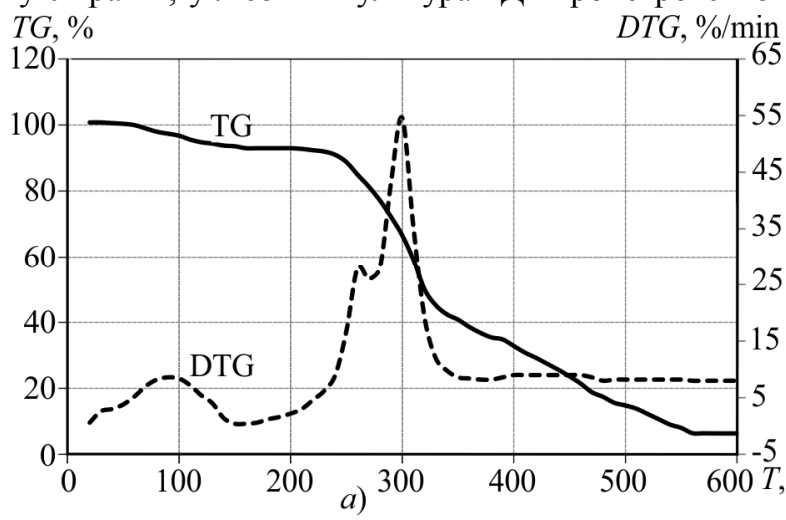

Рис. 1. Результати термічного аналізу деревини (а) та кори (б) роб

На цьому етапі термічного розкладання деревини та кори робінії несправжньоакації на кривих DTA, за температурного діапазону $70-200{ }^{\circ} \mathrm{C}$ фіксують ендотермічний мінімум. В інтервалі температур 120-200 ${ }^{\circ} \mathrm{C}$ термодеструкція деревини і кори майже не відбувається, лише в незначній кількості досліджувані зразки втрачають конституційну воду, особливо кора робінії, про що свідчить незначний ендотермічний ефект з максимумом за $180{ }^{\circ} \mathrm{C}$, де зафіксовано додаткову втрату маси (рис. 2).

На наступному етапі піролізу $\left(200-350{ }^{\circ} \mathrm{C}\right)$ встановлено початок істотної деструкції як деревини, так і ко- го, Верхньодніпровського, Васильківського та Новомосковського лісових господарств, підпорядкованих державному Агентству лісових ресурсів України. Для оцінювання термохімічних змін, що відбуваються в коpi i деревині, застосовували термогравіметричний (TG), диференційно-термогравіметричний (DTG) i диференційно-термічний (DTA) аналізи.

Термогравіметричний аналіз зразків деревини робінії несправжньоакації здійснювали на дериватографі Q - 1500D системи "F. Paulik - J. Paulik - L. Erdey", чутливість гальванометрів TG, DTG, DTA становила 500 мкВ, з реєстрацією аналітичного сигналу втрати маси та теплових ефектів. Зразки деревини і кори аналізували в динамічному режимі зі швидкістю нагрівання $10{ }^{\circ} \mathrm{C} /$ хв в атмосфері повітря. Маса зразків становила 100 мг. Еталонний зразок - $\mathrm{Al}_{2} \mathrm{O}_{3}$.

Енергію активації термоокиснювальної деструкції зразків визначено за методом Бройдо (Broido, 1969). Для цього розраховували значення подвійного логарифма для кожної температури з використанням залежності

$$
\ln \left(\ln \frac{100}{100-\Delta m}\right)=-\frac{E}{R} \cdot \frac{1}{T}
$$

де: $m$ - маса зразка, \%; $E$ - енергія активації, кДж/моль; $R$ - універсальна газова стала, 8,314 Дж/(моль $К$ К); $T$ температура, К. Значення енергії активації $\left(E_{\text {д }}\right)$ визначали за формулою

$$
E_{\text {Д }}=\operatorname{tg} \phi \cdot R
$$

Статистичне оброблення дослідних даних, математичне моделювання проводили 3 використанням програм "Statistica 10" та "Microsoft Excel-2016".

Результати дослідження та їх обговорення. Аналіз даних термічного аналізу показав, що на першому етапі піролізу, до $120^{\circ} \mathrm{C}$ для зразків деревини і кори робінії несправжньоакації відбувається видалення вологи, тобто незв'язаної води, без деструкції структурних компонентів деревини i кори. Втрата маси деревини при цьому становить 5,2-6,0 \%, для кори $-11,6 \%$ (рис. 1).

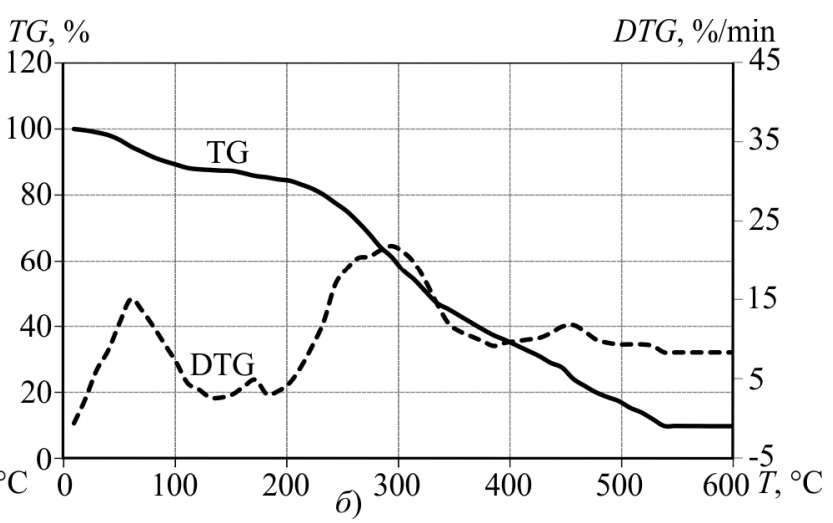

ри. У зазначеному температурному діапазоні відбувається розкладання геміцелюлоз та найменш стійких фрагментів лігнінів (Utgof, 2014). Для деревини робінії несправжньоакації температура початку інтенсивної деструкції деревини становила $232{ }^{\circ} \mathrm{C}$, кори - $222{ }^{\circ} \mathrm{C}$, втрата маси: деревини - 7,8 \%, кори $-16,3 \%$.

Термічне розкладання геміцелюлоз, целюлози і лігніну відбувається в інтервалах температур 225-325 ${ }^{\circ} \mathrm{C}$, $305-375^{\circ} \mathrm{C}$ і $250-500{ }^{\circ} \mathrm{C}$ відповідно (Shen et al., 2009). За температури $260{ }^{\circ} \mathrm{C}$, деревина набула бурого забарвлення, що можна пояснити втратою конституційної води та незначної кількості реакційної вологи, мураши- 
ної і оцтової кислот. Частину оцтової кислоти деревина віддає головно внаслідок відщеплення ацетильних груп від геміцелюлоз (Safi et al., 2004).

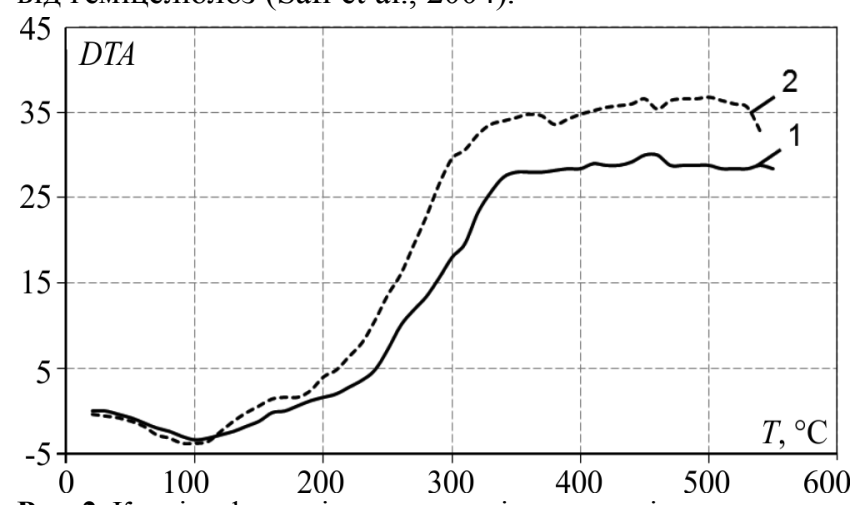

Pис. 2. Криві диференціального термічного аналізу деревини (1) та кори (2) робінії несправжньоакації в окислювальному середовищі

В інтервалі $350-420^{\circ} \mathrm{C}$ відбувається інтенсивне розкладання целюлози і лігніну з утворенням рідких і газоподібних продуктів піролізу вугілля. У межах температур $420-500{ }^{\circ} \mathrm{C}$ завершується термодеструкція лігніну і відбувається утворення коксу, що виникає в процесі термічного розкладання деревини. За температури $500^{\circ} \mathrm{C}$ фіксують вихід коксового залишку. Починаючи $3500{ }^{\circ} \mathrm{C}$ і до $600{ }^{\circ} \mathrm{C}$ відбувається прожарювання вугілля, що утворилося внаслідок термічної деструкції деревини. Розкладання деревини 3 утворенням коксового залишку практично завершується, і відбувається трансформація структури коксу, майже з постійною швидкістю.

Підвищення температури у досліджуваному процесі понад $500{ }^{\circ} \mathrm{C}$ призводить до відокремлення незначної частки $(1,5-0,2 \%)$ важких смол, значно збільшується вихід неконденсованих газів, що становить 0,15-0,40 м³ на 1 кг абсолютно сухої маси і утворює вугілля із вмістом вуглецю: 80-95 \%. При цьому коксовий залишок деревини газифікується або спалюється до зольного залишку.

За температури $600{ }^{\circ} \mathrm{C}$ встановлено вихід зольного залишку, тобто видалення залишкових функціональних груп, тому в інтервалі температур $350-600{ }^{\circ} \mathrm{C}$ відбувається накладання незначних ендо- та екзотермічних ефектів. Незначна термостабільність робінії несправжньоакації може бути пов'язана 3 наявністю у твердолистяних породах значної кількості пентозанів, найменш стійких до нагрівання.

Енергія активації термоокиснювальної деструкції це надлишок енергії, що $є$ необхідною для руйнування хімічних зв'язків, які утворюють основу ланцюга полімеру, під впливом тепла і кисню повітряного середовища (Utgof, 2014). Запропоновано статистично достовірні математичні моделі для оцінювання залежності втрати маси від температури деструкції складників надземної фітомаси досліджуваного деревного виду (рис. 3). Величини цього параметра збільшуються з утворенням зв'язків між макромолекулами полімеру. За рівних інших умов ефективна енергія активації термоокиснювальної деструкції є мірою стійкості біополімерів. Тому, чим більший ступінь зшивання макромолекул, тим вище значення енергії активації.

Розраховані величини енергії активації і відповідні їм температурні діапазони та інтервали зміни ступеня конверсії для компонентів фітомаси представлені в табл.
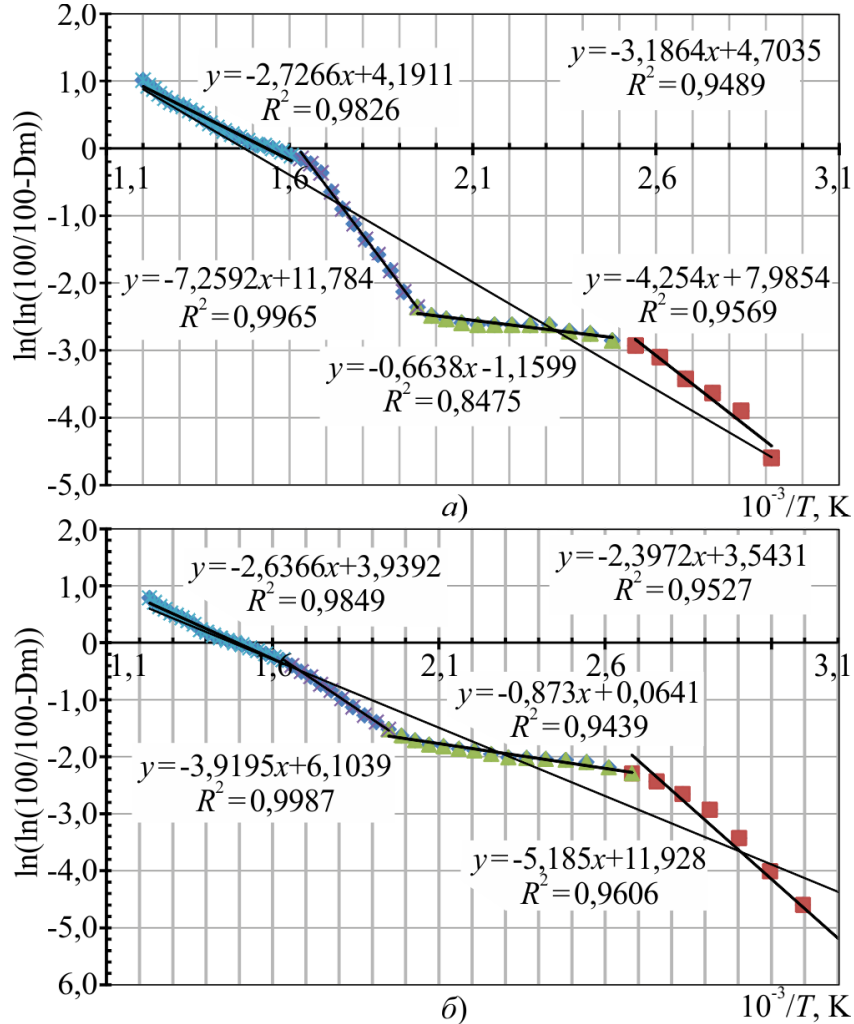

Рис. 3. Логарифмічна залежність $\Delta \mathrm{m}$ від Т під час термічної деструкції деревини (а) та кори (б) робінії в окислювальному середовищі

Таблиця. Енергія активації у різних температурних інтервалах

\begin{tabular}{|c|c|c|c|c|c|c|}
\hline \multirow{3}{*}{ 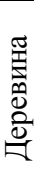 } & $\begin{array}{l}\text { Інтервал тем- } \\
\text { ператури, }{ }^{\circ} \mathrm{C}\end{array}$ & $70-130$ & $\begin{array}{l}130- \\
240\end{array}$ & $\begin{array}{l}240- \\
350\end{array}$ & $\begin{array}{c}350- \\
560\end{array}$ & $70-560$ \\
\hline & & & 5519 & ,353 & 2,669 & 26,402 \\
\hline & $\begin{array}{l}\text { Ступі } \\
\text { клада }\end{array}$ & & & & $0,628 \div 1$ & \\
\hline \multirow{3}{*}{ 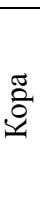 } & & & $\begin{array}{l}100- \\
240 \\
\end{array}$ & $\begin{array}{l}240- \\
340\end{array}$ & $\begin{array}{l}340- \\
540\end{array}$ & \\
\hline & \begin{tabular}{|l} 
Енері \\
ціï., $\mathrm{K}$
\end{tabular} & & 7,258 & 32,587 & 21,921 & 19,930 \\
\hline & $\begin{array}{l}\text { Ступі } \\
\text { клада }\end{array}$ & 4 & $\begin{array}{c}0,104 \div \\
0,217\end{array}$ & $\begin{array}{c}0,217 \div \\
0,587\end{array}$ & 0, & \\
\hline
\end{tabular}

Значний ступінь термічного розкладання кори робінії зафіксовано в інтервалі температур $130-240^{\circ} \mathrm{C}$, тоді як у деревині $-240-360{ }^{\circ} \mathrm{C}$.

Висновки. Відмінності хімічного складу деревини і кори робінії несправжньоакації за основними біополімерними компонентами зумовлюють неоднакову кінетику термодеструкції досліджуваних структурних компонентів надземної фітомаси, про що свідчить залежність значення енергії активації цього процесу.

Деревина і кора незначно відрізняються за здатністю утримувати воду, на що вказують теплові ефекти втрати води та температурні максимуми на кривій DTG. Деревина робінії характеризується значнішою термостабільністю, ніж кора.

\section{Перелік використаних джерел}

Broido, A. A. (1969). Simple. J. Polymer of Science, 7(3), 1761-1763. Guo, F., \& Zhong, Z. (2018). Co-combustion of anthracite coal and wood pellets: Thermodynamic analysis, combustion efficiency, pollutant emissions and ash slagging. Environmental Pollution, 239, 21-29. https://doi.org/10.1016/j.envpol.2018.04.004

Haberle, I., Skreiberg, O., Lazar, J., \& Haugen L. (2017). Numerical models for thermochemical degradation of thermally thick woody biomass, and their application in domestic wood heating appliances 
and grate furnaces. Progress in Energy and Combustion Science, 63, 204-252. http://dx.doi.org/10.1016/i.pecs.2017.07.004

Órfão, J. J. M., Antunes, F. J. A., \& Figueiredo, J. L. (1999). Pyrolysis kinetics of lignocellulosic materials - three independent reactions model. Fuel, $\quad$ 78, 349-358. https://doi.org/10.1016/S0016-2361(98)00156-2

Pandey A., Bhaskar T., Stöcker, M., \& Sukumaran, M. (2015). Recent Advances in Thermochemical Conversion of Biomass. Elsevier, $504 \mathrm{p}$.

Poletto, M., Dettenborn, J., Pistor, V., Zeni, M., \& Zattera, A. J. (2010). Materials produced from plant biomass. Part I: Evaluation of thermal stability and pyrolysis of wood. Materials Res 13(3), 375-379. https://doi.org/10.1590/S1516-14392013005000112

Röder, M., \& Thornley, P. (2018). Waste wood as bioenergy feedstock. Climate change impacts and related emission uncertainties from waste wood based energy systems in the UK. Waste Management, 74, 241-252. https://doi.org/10.1016/j.wasman.2017.11.042
Safi, M. J., Mishra, I. M., \& Prasad, B. (2004). Global degradation kinetics of pine needles in air. Thermochimica Acta, 412(1-2), 158167. https://doi.org/10.1016/j.tca.2003.09.017

Shen, D. K., Gu. S., Luo, K. H., Bridgwater. A. V., \& Fang. M. X. (2009). Kinetic study on thermal decomposition of woods in oxidative environment. Fuel, 88, 1024-1030. https://doi.org/10.1016/j.fuel.2008.10.034

Tan, A. G., \& Stotta, J. B. (1989). Fluidized-bed differential thermal analysis of wood. Fuel. 68(10), 1275-1279. https://doi.org/10.1016/0016-2361(89)90242-1

Utgof, S. S. (2014). Identifikatciia khimicheskikh i mekhanicheskikh izmenenii $\mathrm{V}$ uplotnennoi termomekhanicheskim sposobom drevesine olkhi. Khimiia i tekhnologiia pererabotki drevesiny, 4, 124-129. [In Russian].

Vichnevsky, S., Fuhr, B., \& Melnichuk, J. (2003). Characteization of wood and non-wood mechanical pulps by differential thermal analysis. J. Pulp \& Paper Sci, 29(1), 17-20.

С. А. Сытник, И. В. Рула

Днепровский государственный аграрно-экономический университет, г. Днепр, Украина

\section{ТЕРМИЧЕСКИЙ АНАЛИЗ ДРЕВЕСИНЫ КОРЫ РОБИНИИ ПСЕВДОАКАЦИИ В ДРЕВОСТОЯХ СЕВЕРНОЙ СТЕПИ УКРАИНЫ}

С помощью методов термогравиметрии - термогравиметрической кривой (ТГ) и дифференциальной термогравиметрической кривой (ДТГ), или кривой скорости изменения массы исследуемого образца, исследована термодеструкция древесины и коры основной лесообразующей породы искусственных лесных насаждений Северной Степи Украины - робинии псевдоакации (Robinia pseudoacacia L.). Термический анализ образцов древесины и коры осуществлен в окислительной (воздух) атмосфере. Установлены стадии термического разложения древесинного вещества и коры в условиях программируемого нагрева до $600{ }^{\circ} \mathrm{C}$ со скоростью $10^{\circ} \mathrm{C} /$ мин (ТГ/ДТГ/ДТА), их температурные интервалы, потеря массы, интенсивность потери массы, тепловые эффекты. На основе анализа величин энергии активации на отдельных стадиях термического разложения и зависимостей энергии активации от степени конверсии древесины и коры, а также из сравнения убыли массы на соответствующих стадиях термодеструкции, тепловых эффектов, остаточной массы и других параметров ТГ/ДТГ, охарактеризована древесина и кора. Выявлено большое содержание конституционной воды в составе образцов. Древесина робинии отличается более значительной термостабильностью, чем кора. Предложены математические модели для оценивания зависимости потери массы от температурной деструкции составляющих надземной фитомассы (коры, древесины) исследуемого древесного вида.

Ключевые слова: древесина; кора; окислительная термодеструкция; термогравиметрия; тепловые эффекты.

S. A. Sytnyk, I. V. Rula

Dnipro State Agrarian and Economic University, Dnipro, Ukraine

\section{THE THERMAL ANALYSIS OF WOOD AND BARK OF BLACK LOCUST STANDS WITHIN NORTHERN STEPPE OF UKRAINE}

The thermal degradation of the wood and bark of the main forest-forming spesies of artificial forest plantations of the Northern Steppe of Ukraine - Black locust (Robinia pseudoacacia L.) has been investigated using thermogravimetric methods - a thermogravimetric curve (TG) and a differential thermogravimetric curve (DTG), or a curve of the rate of change in the mass of the investigated sample. Thermal analysis of samples of wood and bark was carried out in an oxidizing (air) atmosphere. Some stages of thermal decomposition of wood and bark under conditions of a programmable heating up to $600^{\circ} \mathrm{C}$ at heating rates $10^{\circ} \mathrm{C} / \mathrm{min}$ (TG/DTG/DTA) and their temperature intervals, mass loss, mass loss intensity and thermal effects have also been investigated. Wood and bark samples were fully characterized from that data which deals with the activation energy analysis at the individual stages of thermal decomposition. The dependences of the activation energy on the degree of conversion, as well as by comparison of the mass loss at the appropriate stages of the thermal degradation, thermal effects, residual mass and some other parameters of TG/DTG have also been evaluated. A greater content of constitutional moisture in the composition of the bark samples with decrease in the temperature of the onset of intensive destruction of the bark in comparison with wood have been revealed. The results of thermogravimetric measurements were analysed in the framework of the kinetic model of Brodo. The activation energy of processes of bark and wood destruction in each temperature range and in the whole investigated range is calculated and mathematical models are proposed for estimating the dependence of mass loss on the temperature degradation of the components of the aboveground phytomass of the studied forest-forming species. Comparison of DTA curves showed that the thermal effect of thermooxidative destruction of the bark as a whole is greater than that of wood, which correlates well with a decrease in the activation energy.

Keywords: wood; bark; pyrolysis; thermal oxidative destruction; thermogravimetry; thermal effects. 